\title{
INVOLVEMENT OF COMBATANT IN PROFESSIONAL CREATIVE ACTIVITY AS A FACTOR OF HIS SOCIAL ADAPTATION
}

\author{
Tatiana Shapovalova ${ }^{1}$, Andriana Paslavska ${ }^{2}$ \\ Lviv Polytechnic National University, Lviv, Ukraine \\ ${ }^{1}$ Candidate of Economic Sciences Associate Professor of Department of Sociology and Social \\ Work \\ ${ }^{2}$ Student of master's programprogram «Social work » of Department of Sociology and Social Work
}

Background: The problems of social adaptation and employment of people who were in unusual conditions for civilians, in combat zones, preserving their health and working capacity after the influence of extreme factors is extremely actual today. Investigate how political instability in the country, problems in the economy and very high competition in the labor market affect the professional creative activity of combatants.

Purpose: To analyze the views of contemporary domestic and foreign researchers on the process of social adaptation of military personnel. To investigate how social adaptation of participants in hostilities in Ukraine is taking place, and what attention is paid to a decent quality of life for military personnel.

Methods: To determine the current state of adaptation of military personnel used theoretical methods of research. The results of the analysis of texts of scientific publications, legislative acts and empirical research reports are considered. The article deals with various aspects of the social adaptation of combatants.

Results: Challenges pertaining to the realization of social adaptation in Ukraine include three main aspects. social adaptation. Therefore, it should be made as accessible as possible to each of these categories. To properly organize the social adaptation of people in this category, you need to take care of educational needs and constantly try to improve them.

Conclusion: The program of social adaptation of servicemen to civilian life is an important component of how the state cares for the circle of such persons. Thus, the best years of the Defense Ministry of Ukraine and the security structures give protection and maintenance of the security of the state, and at the end of the Defense Ministry and the departmental security structures consciously forget about them and do not want to participate in the future of their former subordinates - social adaptation. Therefore, there is a problem in our society - people who serve the interests of the state and are hypothetically in the public service, the leadership of the state should take care of their further destiny, and facilitate the further realization of participants of hostilities in professionally creative activity. The state guarantees the servicemen and their family members social and legal protection in accordance with the laws and regulations adopted in accordance with them.

Keywords: military, social adaptation, classification of professions, adaptation, combatants, a group of society, professional activity.

Соціальна адаптація - процес активної адаптації учасника бойових дій до нових умов проживання в громадянському суспільстві 3 своєрідною системою взаємовідносин. Успішність соціальної адаптації - це добре співвідношення між потребами людини і вимогами певного соціального середовища.

Відомо, що на швидкість соціальної адаптації впливає дві основні умови:

- зовнішні - можливість сприйняття життєвих обставин,

- $\quad$ внутрішніх - сприйняття самими військовослужбовцями змін.

Учасники та постраждалі внаслідок військових дій $є$ представниками такої категорії населення, що потребує особливого ставлення. Розглядаючи цю групу населення надзвичайно важливо є проблема пристосування до мирного життя. (Красильщиков, 2005, с. 95)

Варто зазначити, що учасників бойових дій належать насамперед військовослужбовці, що брали участь у виконанні бойових завдань для захисту Батьківщини, як у військовий, так і в мирний час. 
Статус осіб, що вважаються учасниками бойових та гарантії їх соціального захисту прописані в Законі України «Про статус ветеранів війни, гарантії їх соціального захисту» від 22 жовтня 1993 р.

Безумовно ветерани війни, особи, які мають заслуги перед Батьківщиною, учасники Революції Гідності, їх родини є активною групою суспільства, якій держава має надати особливі умови для власного розвитку, зайнятості, самозайнятості, започаткування власних справ, чим забезпечує економічне зростання України.

Необхідно зазначити, що соціальна адаптація військовослужбовців включає такі складові як: психологічну, правову та професійну.

Таким чином, незважаючи на визнання важливості інших сфер соціальної адаптації військовослужбовців, зосереджено увагу переважно на проблемах, пов'язаних з професійною підготовкою та працевлаштуванням колишніх військових, їх адаптації до умов ринку праці. Подібні уявлення про цей процес чітко прослідковуються і у національному законодавстві.

Все із освітньої програми для військовослужбовців має бути представлене у вільному доступі. Розробляють та реалізуються плани заходів професійної орієнтації для ветеранів війни, підвищення кваліфікації та інші заходи в цьому руслі. Повернення учасників бойових дій до мирного життя, це не легкий процес, війна змінює людей, не всі повертаються тими ким були до. Адаптація військовослужбовців до мирного життя, складний процес, який потребує багато зусиль. В багатьох випадках не обійтись без психологів. (Кучеренко, Хоменко, 2017, с. 7)

В розпорядженні Кабінету Міністрів «Про схвалення Концепції Державної цільової програми соціальної і професійної адаптації військовослужбовців, які підлягають звільненню, та осіб, звільнених з військової служби, на період до 2017» визначено основні етапи залучення до професійної діяльності учасників бойових дій та які привілеї їм надаються. До основних таких інструментів входять: Створення системи мотивації роботодавців до працевлаштування ветеранів війни, впроваджено заходи для забезпечення сприятливих умов ведення бізнесу ветеранами війни, самозайнятість ветеранів війни, розроблення та впроваджені дієвих інструментів фінансової підтримки малого та середнього ветеранського підприємництва, а також запроваджено державну програму підтримки ветеранського підприємництва.

\section{References}

Krasylshhykov, A. (2005). Socialna adaptaciya zvilnenyx u zapas vijskovosluzhbovciv (problemy ta dosvid yix vyrishennya v Ukrayini ta zarubizhny’x krayinax). Demografiya ta socialna ekonomika, $88-95$.

Kucherenko, S.,\& Xomenko, N., (2017) Organizacijni osoblyvosti socialno-psyxologichnoyi adaptaciyi vijskovosluzhbovciv, yaki braly uchast u bojovyx diyax, do umov myrnogo zhyttya. Problemy ekstremalnoyi ta kryzovoyi psyxologiyi, 21, 1-9.

Ukrayina. Zakon «Pro status veteraniv vijny, garantiyi yix socialnogo zaxystu» №145 (1993). URL: https://zakon.rada.gov.ua/laws/show/3551-12/ed20180224

Ukrayina. Rozporyadzhennya Kabinetu Ministriv 1068-r (2013) Pro sxvalennya Koncepciyi Derzhavnoyi cilovoyi programy socialnoyi i profesijnoyi adaptaciyi vijskovosluzhbovciv, yaki pidlyagayut zvilnennyu, ta osib, zvilnenyx z vijskovoyi sluzhby’, na period do 2017 roku. URL: https://zakon.rada.gov.ua/laws/show/1068-2013-r

\section{Список використаної літератури}

Красильщиков, А. (2005). Соціальна адаптація звільнених у запас військовослужбовців (проблеми та досвід їх вирішення в Україні та зарубіжних країнах). Демографія та сочіальна економіка, 88 - 95.

Кучеренко, С.,\& Хоменко, Н., (2017) Організаційні особливості соціально-психологічної адаптації військовослужбовців, які брали участь у бойових діях, до умов мирного життя. Проблеми екстремальної та кризової психології, 21, 1-9.

Україна. Закон «Про статус ветеранів війни, гарантії їх соиіального захисту» №145 (1993). URL: https://zakon.rada.gov.ua/laws/show/3551-12/ed20180224 
Україна. Розпорядження Кабінету Міністрів 1068-р (2013) Про схвалення Концепиії Державної изільової програми соціальної $i$ професійної адаптації військовослужбовців, які підлягають звільненню, та осіб, звільнених з військової служби, на період до 2017 року. URL: https://zakon.rada.gov.ua/laws/show/1068-2013-p

\section{Contact information:}

Shapovalova Tetiana Viktorivna

gg39358@gmail.com

Paslavska Andriana

andrianapaslavska@gmail.com 